\title{
A Comparison of Covid-19 Patient Characteristics Before versus After Partial
}

\section{Lockdown in Vietnam}

\author{
Hoang-Long Vo ${ }^{1, *}$, Kim-Duy Vu ${ }^{1}$ \\ ${ }^{1}$ Institute for Preventive Medicine and Public Health, Hanoi Medical University, Hanoi 100000, \\ Vietnam \\ * Correspondence:
}

Hoang-Long Vo, M.D., vohoanglonghmu@ gmail.com

Word count: 2702

Running Title: Characteristics Before versus After Partial Lockdown 


\section{What is already known on this topic}

- Most of Covid-19 confirmed patients in Vietnam were acquired overseas.

- In Vietnam, Covid-19 epidemic had the low estimated reproduction ratio $\left(R_{0}\right)$ and SARS-CoV-2 spread was on the downward trend before July 25.

\section{What this study adds}

- Covid-19 confirmed patients were older in the time after lockdown end compared to in the period before lockdown end by a median of 5 years.

- All discharged Covid-19 patients and no Covid-19 death were in the phase before lockdown, while post lockdown period had still remained significant patients being under treatment, especially reported first fatalities.

- Continuous volume of people returning Vietnam from abroad through two stages during the Covid-19 epidemic.

- Our analysis might be considered as a prompt reference source for further in-depth surveys to understand the adaptive models of Covid-19 patients among different provinces. 
medRxiv preprint doi: https://doi.org/10.1101/2020.08.27.20183616; this version posted September 7, 2020. The copyright holder for this preprint (which was not certified by peer review) is the author/funder, who has granted medRxiv a license to display the preprint in perpetuity.

It is made available under a CC-BY-NC 4.0 International license .

0 Abstract

1 Background. Given the Covid-19' sudden rapid spread in the community since 25 July 2020, an

2 updated analysis of Covid-19 cases was conducted to examine the differences of characteristics

3 of Covid-19 patients before versus after partial lockdown end in Vietnam.

4 Methods. Data of 569 Covid-19 patients confirmed SARS-CoV-2 infection from 23 January to

531 July was collected from available official databases. We divided Covid-19 situation timeline

6 into two main periods, before lockdown end (23 January - 22 April) and after lockdown end (23

7 April - 31 July).

8 Results. We found significant variations in the distribution of Covid-19 patients among different

9 provinces between two periods. Covid-19 confirmed patients were older in the time after

10 lockdown end compared to in the period before lockdown end by a median of 5 years. All

11 discharged Covid-19 patients and no Covid-19 death were in the phase before lockdown, while

12 post lockdown period had still remained significant patients being under treatment, especially

13 reported first fatalities. The number of Covid-19 patients who returned from other countries

14 (excluding China) slightly increased through two stages ( $\mathrm{p}>0.05)$, partially showing that the

15 continuous volume of people returning Vietnam from abroad during the Covid-19 epidemic.

16 Conclusions. Our analysis indicated demographic and epidemiological disparity of Covid-19

17 patients before versus after loosening the national partial lockdown in Vietnam. It is important to

18 suggest that, proactive efforts in Covid-19 control after partial lockdown end will be effective

19 when the measures to closely control and monitor repatriation and immigration via the borders of

20 Vietnam are strictly enforced.

21 Keywords: SARS-CoV-2; Covid-19; patient characteristics; Comparison; Vietnam 
medRxiv preprint doi: https://doi.org/10.1101/2020.08.27.20183616; this version posted September 7, 2020. The copyright holder for this preprint (which was not certified by peer review) is the author/funder, who has granted medRxiv a license to display the preprint in perpetuity. It is made available under a CC-BY-NC 4.0 International license .

\section{Introduction}

23 Since the beginning of the coronavirus disease 2019 (Covid-19) crisis, the lockdown has been

24 considered a key policy response in many countries to prevent the further spread of the severe

25 acute respiratory syndrome coronavirus 2 (SARS-CoV-2) which causes the disease. The

26 implementation of the lockdown order, however, has varied in countries and territories around

27 the world, thanks to the unpredictable situation of the pandemic [1]. Vietnam is one of the few countries achieving effective control of Covid-19 outbreak after the implementation of lockdown strategy [2]. Under Directive No. 16/CT-TTg issued in March 31, 2020, a "stay-at-home" order was imposed nationwide to curb the spread of the contagion, limit the number of infections and casualties, and alleviate the pressure on the health service providers. The effectiveness of such outbreak control was evidenced by the fact that there were only 59 new infected cases confirmed during the first 14-day nationwide social distancing (from April 1 to 14, 2020), equaled to $40 \%$ of the two weeks prior to the national lockdown [3]. Of these, there were 30 confirmed cases in isolation zones and 29 confirmed cases in the community [3]. Within 99 days since April 15, Vietnam had confirmed no community transmission despite extensive testing. While in many regions of the world strict Covid-19 lockdown orders had still been in effect, the Government of Vietnam relaxed social distancing rules for almost all provinces and cities on 23 April [4]. The early success in Vietnam' epidemic control has mainly attributed to the national emergency response across the whole sociopolitical system, in particular, 22-day nationwide lockdown. new case were reported in Da Nang City [5]. This disruption made the Covid-19 pandemic in

43 Vietnam more unforeseeable than ever [6], [7], [8]. Immediately, contact tracing efforts as well as epidemiologic investigations have been strengthened under the strong guidance of the

45 Vietnamese Prime Minister, yet the source of the infection is not known in several new cases [8], 
medRxiv preprint doi: https://doi.org/10.1101/2020.08.27.20183616; this version posted September 7, 2020. The copyright holder for this preprint (which was not certified by peer review) is the author/funder, who has granted medRxiv a license to display the preprint in perpetuity.

It is made available under a CC-BY-NC 4.0 International license.

46 [9]. With the estimation of the reproduction ratio $\left(R_{0}\right)$ for 257 first Covid-19 patients in Vietnam

47 (between 23/1/2020 and 10/4/2020), a Huy G. Nguyen' early analysis revealed the downward

48 trend of the epidemic in this country [10]. However, the potential SARS-CoV-2 transmission in

49 the community is not reflective of current reality in each stage under Government' strict

50 restrictions. An initial understanding of the characteristics of Covid-19 patients detected before

51 and after lockdown end in Vietnam is needed to suggest prompt and efficient actions in the

52 worst-case scenarios for in Vietnam. Given the Covid-19' rapid spread, an updated analysis of

53 cases was conducted to examine the differences of characteristics of Covid-19 patients before

54 versus after lockdown end in Vietnam.

Methods

56 In this paper, we collected data of Covid-19 patients who were confirmed SARS-CoV-2

57 infection from 23 January to 31 July, 2020. We divided Covid-19 situation timeline from 23

58 January to 31 July 2020 into two main periods, before lockdown end (23 January - 22 April,

59 2020) and after lockdown end (23 April - 31 July, 2020). We selected cut-off point of Covid-19

60 situation timeline in Vietnam on 23 April, 2020 (23 April, 2020 is the day that the Vietnam

61 Government decided to loosen the national lockdown [4]).

62

Data sources

63 Analysis data in this paper was extracted from two sources, official database of the Ministry of

64 Health of Vietnam (MOH) (https://ncov.moh.gov.vn/) and the website of Our World in Data

65 (https://ourworldindata.org/coronavirus\#coronavirus-country-profiles) [11]. A total of 569

66 Covid-19 confirmed patients were consecutively detected from 23 January to 31 July, 2020

67 (Figure 1). 
medRxiv preprint doi: https://doi.org/10.1101/2020.08.27.20183616; this version posted September 7, 2020. The copyright holder for this preprint (which was not certified by peer review) is the author/funder, who has granted medRxiv a license to display the preprint in perpetuity.

It is made available under a CC-BY-NC 4.0 International license.

69 Covid-19 positive case and Covid-19 suspected case were defined according to the Decision No.

70322 / QD-BYT of February 6, 2020 of the Minister of Health for the period before lockdown end

71 [12] and according to the Decision 1344 / QD-BYT 2020 Guidance on diagnosis and treatment

72 of COVID-19 [13] for the period after lockdown. The Vietnam' tests were reported by the WHO

73 and $\mathrm{MOH}$ approved laboratories [12], [13].

74 Covid-19 recovered case before and after lockdown end was defined that, a patient who

75 recovered from Covid-19 and discharged from the health facility met the following criteria: 1) no

76 fever for at least three days; 2) a good general health condition; (3) two samples taken at least 1

77 day apart having negative test results for SARS-CoV-2 [12], [13].

78 Covid-19 death case is a patient with confirmed Covid-19 infection whose death resulted from

79 clinically compatible illness, unless there is an other certain cause of mortality that cannot be

80 related to Covid-19 disease (e.g., trauma). No period of full recovery was recorded between the

81 illness and death.

82 Variables

83 The variables in this analysis were selected on the basis of the availability of above official

84 databases. The variables related to the Covid-19 patient characteristics were divided into

85 subgroups as following: mean age, age group (0-10 years/11-20 years/21-30 years/31-40

86 years/41-50 years/51-60 years/60 years and over), gender (male/female), nationality

87 (Vietnam/others), the history of returning from China (yes/no), the history of returning from

88 other countries (excluding China) (yes/no), and treatment status (under treatment/ discharged/

89 died). 
medRxiv preprint doi: https://doi.org/10.1101/2020.08.27.20183616; this version posted September 7, 2020. The copyright holder for this preprint (which was not certified by peer review) is the author/funder, who has granted medRxiv a license to display the preprint in perpetuity.

It is made available under a CC-BY-NC 4.0 International license.

91 Vietnam' Covid-19 situation timeline was considered as a variable with two main values: (code

92 1) before lockdown end and (code 2) after lockdown end. We used both descriptive and

93 analytical method. While age data was expressed as mean $\square \pm \square$ standard deviation (SD) with

94 interquartile ranges (IQR), categorical variables were presented as frequency with percentage

95 (\%). We estimated the overall proportion of Covid-19 confirmed cases and its percentage before

96 and after lockdown end according to selected demographic and epidemiological characteristics.

97 Chi-square tests and Mann-Whitney U tests were utilized to compare patient' characteristics

98 between two periods. All statistical analyses in this paper were conducted by Stata® 15

99 (StataCorp LLC, USA). The level of statistical significance was set at 0.05.

\section{Results}

Among the 569 patients from 23 January to 31 July 2020, there were 268 patients by 22 April and 301 patients between 23 April and 31 July (Figure 1). Figures 2 illustrated the significant variation in the distribution of Covid-19 patient among different provinces between two periods.

The demographic and epidemiological characteristics of the patients are shown in Table 1. end were older than those in the period before lockdown end by a median of 5 years. Overall, those aged 21-30 years are recorded with the highest number of Covid-19 confirmed cases in both periods $(35.82 \%(\mathrm{n}=96)$ vs. $27.91 \%(\mathrm{n}=84))$. Almost $90 \%(\mathrm{n}=241)$ of patients aged 59 years or younger before lockdown, while this figure after lockdown end was nearly $85 \%(\mathrm{n}=$ 254). There was significant difference in the patient gender between two periods, $45.52 \%$ male

111 before lockdown and 61.79\% male after lockdown.

112 Of 10 Covid-19 patients returned from China, 9 patients $(3.36 \%)$ were in the first period and 1 $113(0.33 \%)$ was in the second period, while no difference between two periods was observed 
medRxiv preprint doi: https://doi.org/10.1101/2020.08.27.20183616; this version posted September 7, 2020. The copyright holder for this preprint

(which was not certified by peer review) is the author/funder, who has granted medRxiv a license to display the preprint in perpetuity.

It is made available under a CC-BY-NC 4.0 International license .

114 according to the number of patients returned from other countries. Besides, the Covid-19 patient'

115 nationality between two periods was also significantly varied (Table 1).

116 Compared to the phase before lockdown with 268 discharged Covid-19 patients (100\%) and no

117 Covid-19 death, post lockdown period had only $34.88 \%$ patients cured and discharged from the

118 facilities with 5 fatalities (1.66\%) and 191 those being under treatment (63.46\%) (Table 1). 
Table 1. Characteristics of the Covid-19 patients detected before versus after lockdown end, 23 January to 31 July 2020 (N = 569)

\begin{tabular}{|c|c|c|c|c|}
\hline \multirow[b]{2}{*}{ Characteristics } & All patients & Before lockdowns end & After lockdowns end & \multirow[t]{2}{*}{$\mathbf{p}$} \\
\hline & $\begin{array}{c}\mathrm{N}=569 \\
192(\operatorname{Jan} 23-\mathrm{Jul} 31)\end{array}$ & $\begin{array}{c}\mathrm{N}=268 \\
91 \text { days (Jan 23-Apr 22) }\end{array}$ & $\begin{array}{c}\mathrm{N}=301 \\
101 \text { days (Apr 23-Jul 31) }\end{array}$ & \\
\hline Gender & & & & $<0,001^{*}$ \\
\hline Male & $308(54.13)$ & $122(45.52)$ & $186(61.79)$ & \\
\hline Female & $261(45.87)$ & $146(54.48)$ & $115(38.21)$ & \\
\hline Age, mean \pm SD (IQR) & $38.56 \pm 16.61(0-90)$ & $35.89 \pm 15.93(0-88)$ & $40.93 \pm 16.86(0-90)$ & $<0,001^{* * *}$ \\
\hline Age group & & & & $<0,001^{*}$ \\
\hline $0-10$ years & $13(2.28)$ & $6(2.24)$ & $7(2.33)$ & \\
\hline $11-20$ years & $44(7.73)$ & $32(11.94)$ & $12(3.99)$ & \\
\hline $21-30$ years & $180(31.63)$ & $96(35.82)$ & $84(27.91)$ & \\
\hline $31-40$ years & $101(17.75)$ & $36(13.43)$ & $65(21.59)$ & \\
\hline $41-50$ years & $86(15.11)$ & $44(16.42)$ & $42(13.95)$ & \\
\hline $51-60$ years & $71(12.48)$ & $27(10.07)$ & $44(14.62)$ & \\
\hline 60 years and over & $74(13.01)$ & $27(10.07)$ & $47(15.61)$ & \\
\hline Nationality & & & & $<0,001^{*}$ \\
\hline Vietnamese & $498(87.52)$ & $220(82.09)$ & $278(92.36)$ & \\
\hline Others & $71(12.48)$ & $48(17.91)$ & $23(7.64)$ & \\
\hline Had returned from China & & & & $0.006^{*}$ \\
\hline Yes & $10(1.76)$ & $9(3.36)$ & $1(0.33)$ & \\
\hline No & $559(98.24)$ & $259(96.64)$ & $300(99.67)$ & \\
\hline $\begin{array}{l}\text { Had returned from other countries } \\
\text { (excluding China) }\end{array}$ & & & & 0.844 \\
\hline Yes & $333(58.52)$ & $158(58.96)$ & $175(58.14)$ & \\
\hline No & $236(41.48)$ & $110(41.04)$ & $126(41.86)$ & \\
\hline Treatment status & & & & $<0,001^{*}$ \\
\hline Under treatment & $191(33.57)$ & $0(0.00)$ & $191(63.46)$ & \\
\hline Discharged & $373(65.55)$ & $268(100.00)$ & $105(34.88)$ & \\
\hline Died & $5(0.88)$ & $0(0.00)$ & $5(1.66)$ & \\
\hline
\end{tabular}




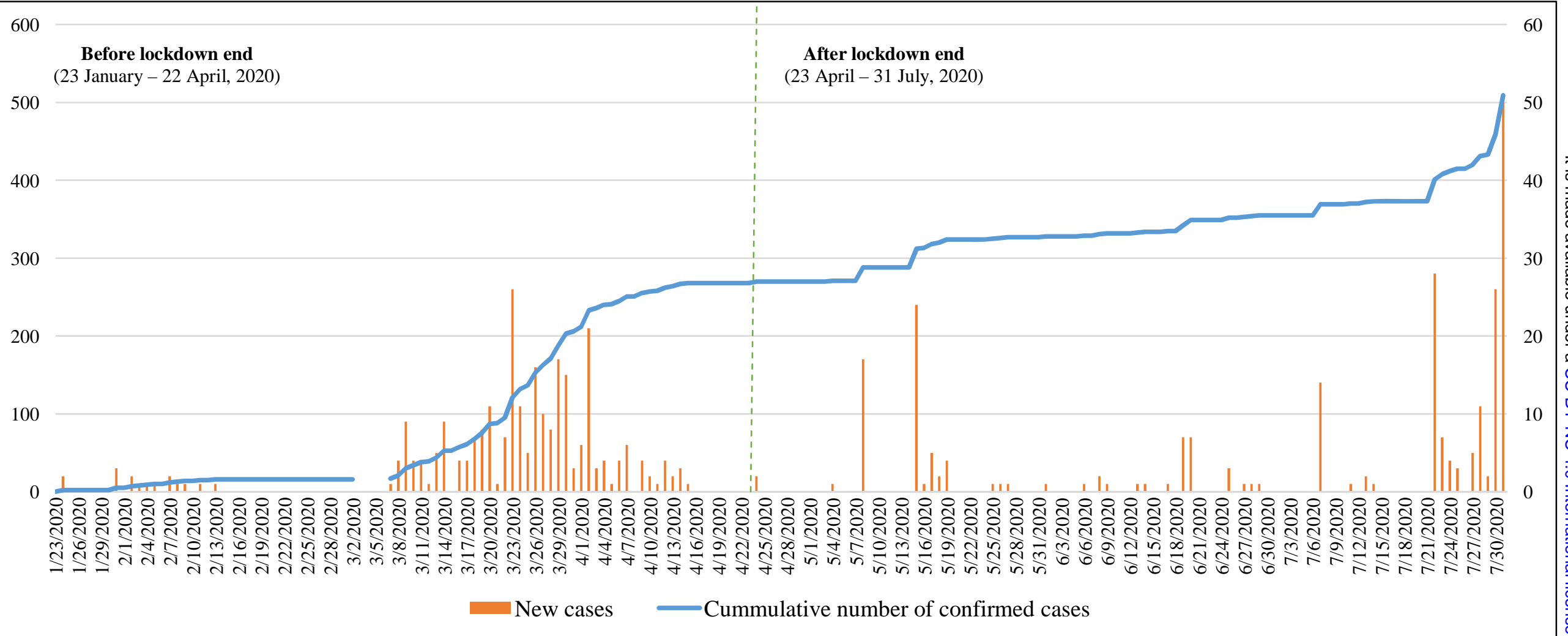

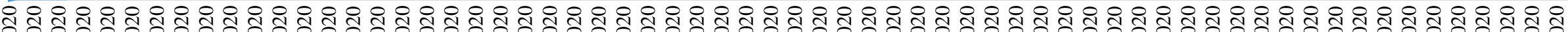

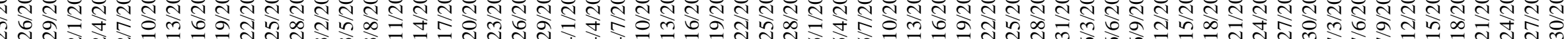

New cases Cummulative number of confirmed cases

Figure 1. The incidence of confirmed Covid-19 cases and its cumulative numbers, 23 January to 31 July 2020 


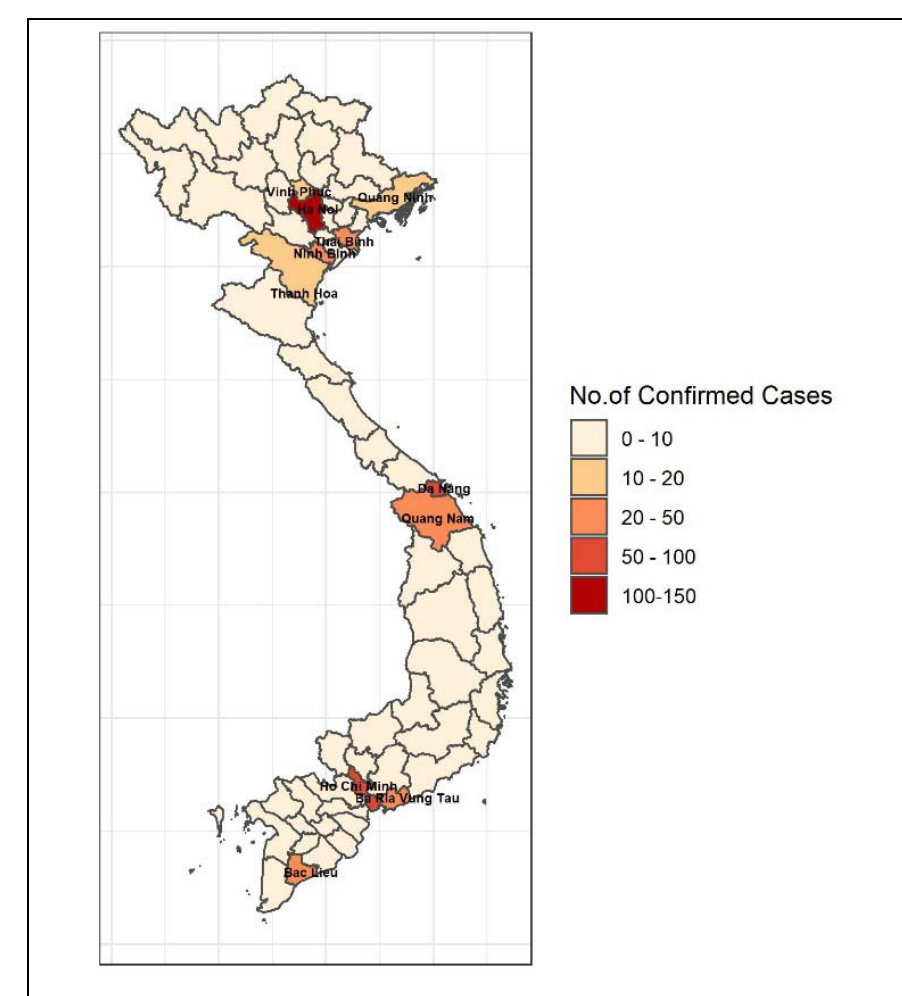

Figure 2a. Distribution of Patients with Confirmed Covid19 Cases across Vietnam by 31 July 2020

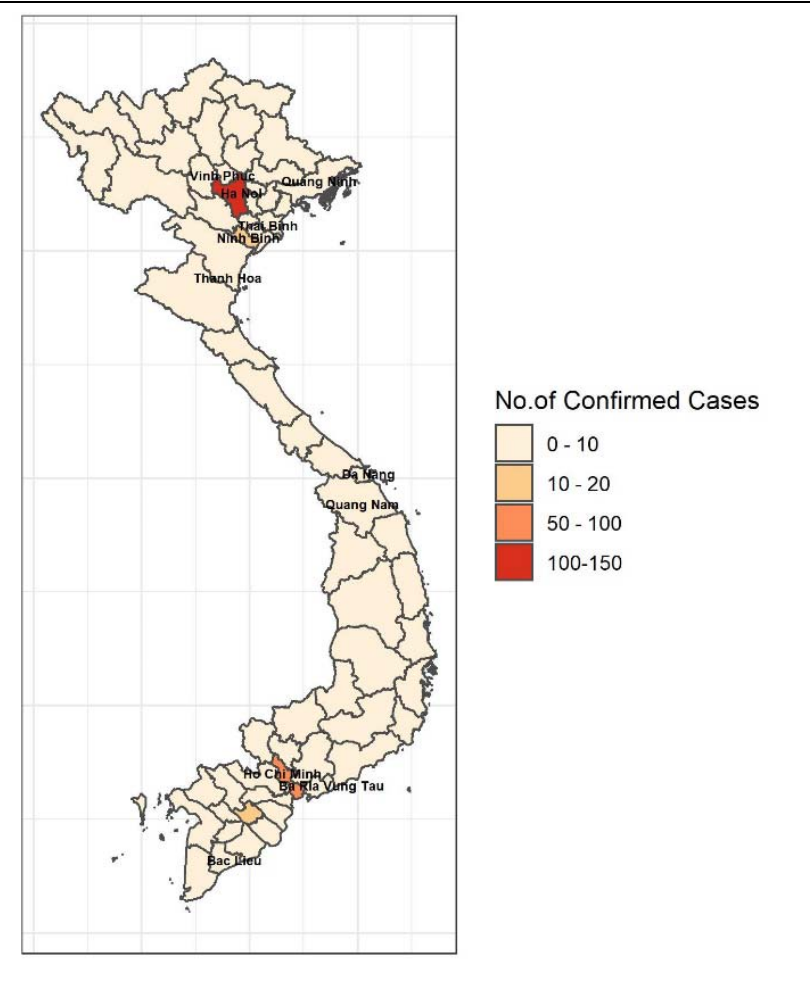

Figure 2b. Distribution of Patients with Confirmed Covid-19 Cases across Vietnam, 23 January - 22 April,

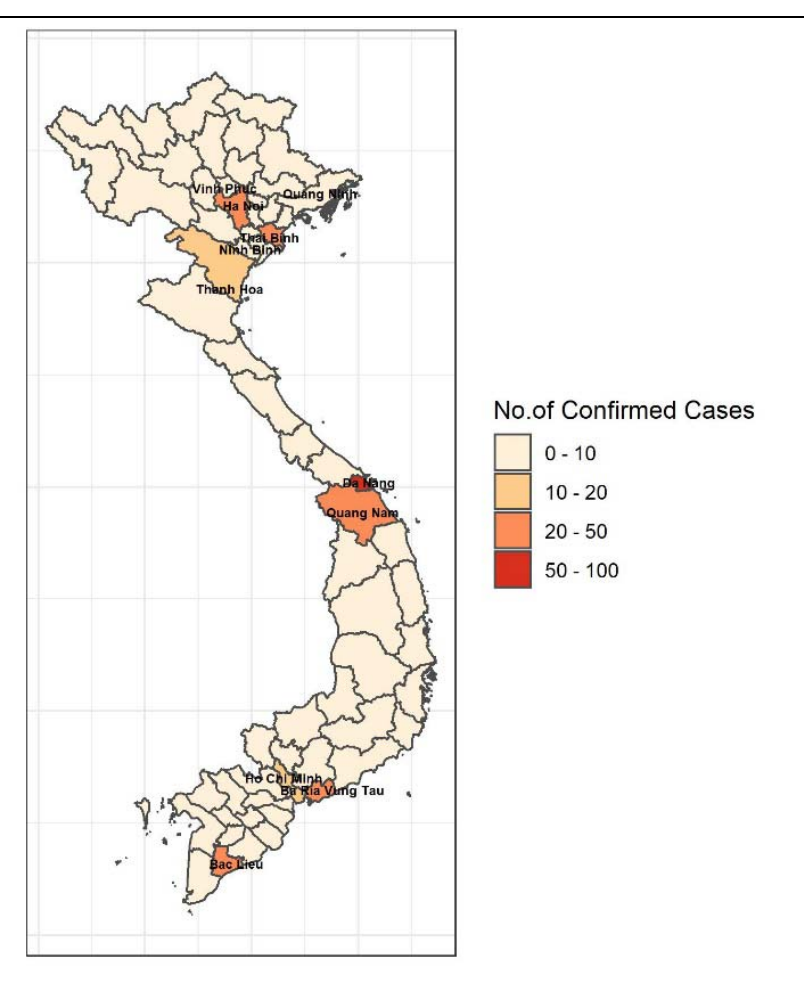

Figure 2c. Distribution of Patients with Confirmed Covid-19 Cases across Vietnam, 23 April - 31 July, 2020 


\section{Discussion}

At the time of writing this article, the first 569 consecutive confirmed cases of Covid-19 through 31 July 2020 are utilized to compare according to two stages, before and after lockdown end in Vietnam. Among the 569 patients, the a median age was 38.56 years, which was significantly lower compared to recent reports in other countries such as 62.2 years in 393 patients in New York City, U.S [14] and 50.1 years in 198 patients in Shanghai, China [15]. Age structure of each country may be the best explanation for the difference in the confirmed case number through two phases. The age distribution of cases was revealed with strong and important role on Covid-19 case fatality [16]. In Vietnam, as compared to before lockdown end, the stage after lockdown had a higher proportion of elder patients. The Covid-19 patient distribution in general is quite similar amongst age groups and those aged 21-30 years are recorded with the highest number of Covid-19 confirmed cases in both periods, implying that SARS-CoV-2 infection risk considerations are not focused solely on any age group. Those in later stage are also patients having pre-existing comorbidities, contributing to the partial explanation of 5 first fatality cases before 31 July. In this analysis, it was observed that significant difference in the gender was shown between two stages (45.52\% male patients before lockdown end vs $61.79 \%$ male patients after lockdown end).

Despite the more and more increasing global Covid-19 patient number with the overload of the health system, Vietnam has still been responding well to the Covid-19 pandemic with the mobilization of the entire political system. Significant difference was observed in the nationality of Covid-19 patients between two phases. During the initial phase of the study timeline, $17.91 \%$ patients $(n=48)$ were residents of other countries, which decreased to $7.64 \%$ patients $(n=23)$ during phase after the lockdown end. This point is mainly because, in the time after lockdown 
medRxiv preprint doi: https://doi.org/10.1101/2020.08.27.20183616; this version posted September 7, 2020. The copyright holder for this preprint (which was not certified by peer review) is the author/funder, who has granted medRxiv a license to display the preprint in perpetuity. It is made available under a CC-BY-NC 4.0 International license .

end, most of them are Vietnamese citizens flown home from abroad [17]. In our analysis, the Vietnamese cases increase in the community after lockdown may be associated with the reopening of domestic tourism in the "new normal" condition after the first Covid-19 wave and the illegal border entry [4], [18], [19]. Current situation requires that, Vietnam' proactive efforts in Covid-19 control will be effective when volume, speed, and reach of travel in tourism are well managed and the measures to closely control and monitor repatriation and immigration via its borders are prioritized. Despite having a long borderline with China, Vietnam only recorded 9 confirmed patients returned from China at the time before lockdown end and only a case after lockdown who had illegally immigrated to Vietnam. On the other hand, we found, the number of Covid-19 patients who returned from other countries (excluding China) slightly increased through two stages, however, this difference was not statistically significant. This result partially shows that the continuous volume of people returning Vietnam from abroad during the Covid-19 epidemic. Such the detection of the Covid-19 cases from overseas is the effort of not only the entire political system in immigration control and management of people returning from abroad in general and but also the Vietnam Border Defense Force in particular. The more clear proof is that, over 16,000 people illegally entering Vietnam have been prevented by the Vietnam Border Defence Force since the beginning of 2020 and, particularly, over 2,400 people have been arrested in July once trespassing on the trail [19].

Our study showed that the difference in the treatment status of Covid-19 patients between before and after lockdown end. Vietnam' early success in the Covid-19 patient treatment was proved by the absolute figure of 268 discharged Covid-19 patients (100\%) before lockdown end. Although the number of the recovered patients, overall, continued to slightly increase from 23 April to 25 July after lockdown end, yet the number of new cases in this phase gradually decreased within 
medRxiv preprint doi: https://doi.org/10.1101/2020.08.27.20183616; this version posted September 7, 2020. The copyright holder for this preprint

(which was not certified by peer review) is the author/funder, who has granted medRxiv a license to display the preprint in perpetuity.

It is made available under a CC-BY-NC 4.0 International license.

three months before Covid-19 outbreak point documented in the community in Da Nang on 25 July. Importantly, all new Covid-19 instances from 23 April to 25 July after lockdown were Vietnamese people who returned from abroad and this risk group was then required to isolate for 14 days [20]. When Vietnam was retaining 99 days without any cases in the community, various countries across the world have been faced a rapid growth in the number of new and fatal cases of Covid-19 [21]. Since 25 July after lockdown, almost patients being treatment in Vietnam have been confirmed SARS-CoV-2 infection, which known as the second wave of Covid-19. In such emerging Covid-19 situation, the community transmission cases reported to be linked to the hospitals in Da Nang where the elder patients with chronic severe diseases such as cancer, chronic kidney disease and dialysis, heart failure, diabetes, or hypertension were being treated [22]. Therefore, compared to the phase before lockdown end (all discharged Covid-19 patients (100\%) and no death), the post-lockdown time recorded the worse situation with mostly patients being treated $(\mathrm{n}=191,63.46 \%)$ and first 5 fatalities $(1.66 \%)$. It should be noted that five fatal cases were identified at the moment of Vietnam' second Covid-19 outbreak after the national lockdown implementation for three months. After synthesizing current analysis data, two main reasons associated with Vietnamese Covid-19 deaths were suggested by the Vietnamese experts. Firstly, the new coronavirus strain detected in second wave of Covid-19 infections there had a faster speed of infection compared to the earlier strain. However, many uncertainties have remained concerning the virus-host interaction and the evolution of the epidemic, and its harmfulness compared to the strain previously existed in Vietnam has been not yet known [22], [23]. Secondly, the presence of multiple coexisting severe illness was reported in Covid-19 fatalities [24]. 
The present results should be viewed with the limitations. First, because the paper' secondary analysis data was collected from two publicly available datasets, the information of the exposure history, clinical symptoms or signs, radiologic assessments, laboratory testing as well as the other risks could be unknown. Second, the challenges in national large-scale coronavirus testing resulted in the underestimated true number of Covid-19 infections. Finally, due the ongoing Covid-19 pandemic with the more complicated situation in Vietnam, the current estimates are temporary at the time of this writing.

\section{Conclusions}

Our short communication illustrated demographic and epidemiological disparity of Covid-19 patients before versus after loosening the national lockdown in Vietnam. The Covid-19 patient distribution in general is quite similar amongst age groups and these patients were largely recorded in the 21-30-year-old group in both periods. Most of the Covid-19 patients are residents of Vietnam and Vietnamese patient number has still increased rapidly during phase after the lockdown end. Importantly after the lockdown period, Vietnam' proactive efforts in Covid-19 control after lockdown end will be effective when the measures to closely control and monitor repatriation and immigration via its borders are strictly enforced. 
medRxiv preprint doi: https://doi.org/10.1101/2020.08.27.20183616; this version posted September 7, 2020. The copyright holder for this preprint

(which was not certified by peer review) is the author/funder, who has granted medRxiv a license to display the preprint in perpetuity.

It is made available under a CC-BY-NC 4.0 International license.

\section{Author Contributions}

Conceptualization: H-LV; Data analysis: K-DV; Methodology: H-LV and K-DV; Supervision:

H-LV; Writing - original draft: H-LV and K-DV; Writing - review and editing: H-LV and K-

DV.

\section{Funding support}

No funding was received for this work.

\section{Acknowledgments}

We thank the Vietnam Ministry of Health for publicly providing the open access Covid-19 databases.

\section{Conflicts of Interest}

The authors 
medRxiv preprint doi: https://doi.org/10.1101/2020.08.27.20183616; this version posted September 7, 2020. The copyright holder for this preprint

(which was not certified by peer review) is the author/funder, who has granted medRxiv a license to display the preprint in perpetuity.

It is made available under a CC-BY-NC 4.0 International license.

\section{References}

1. National responses to the COVID-19 pandemic. 2020 [cited 2020 31/07]; Available from: https://en.wikipedia.org/wiki/National_responses_to the_COVID-19_pandemic.

2. Todd Pollack, et al. Emerging COVID-19 success story: Vietnam's commitment to containment. 2020 [cited 2020 27/07]; This article is one of a series focused on identifying and understanding Exemplars in the response to the Coronavirus pandemic. It is hosted by the Exemplars in Global Health (EGH) platform]. Available from: https://ourworldindata.org/covid-exemplar-vietnam.

3. $\quad$ Duc Tuan. Prime Minister agreed to continue implementing Directive 16 at least until 22/4 in some localities. 2020 [cited 2020 01/08]; Available from:

http://baochinhphu.vn/Tin-noi-bat/Thu-tuong-nhat-tri-tiep-tuc-thuc-hien-Chi-thi-16-itnhat-den-224-tai-mot-so-dia-phuong/393140.vgp.

4. Khanh $\mathrm{Vu}$, Phuong Nguyen, and James Pearson. After aggressive mass testing, Vietnam says it contains coronavirus outbreak. 2020 [cited 2020 28/07]; Available from:

https://www.reuters.com/article/us-health-coronavirus-vietnam-fight-insi/afteraggressive-mass-testing-vietnam-says-it-contains-coronavirus-outbreakidUSKBN22B34H.

5. Vietnam, Which Avoided Coronavirus for 99 Days, Records First COVID-19 Death. [cited 2020 01/08]; Available from: https://time.com/5874146/vietnam-first-coronavirusdeath/.

6. Ministry of Health of Vietnam. Prime Minister: Calculate closely before deciding on social distance. 2020 [cited 2020 02/08]; Available from: https://moh.gov.vn/tin-noibat/-/asset_publisher/3Yst7YhbkA5j/content/thu-tuong-tinh-toan-chat-che-truoc-khiquyet-inh-gian-cach-xa-

hoi?inheritRedirect=false\&redirect=https\%3A\%2F\%2Fmoh.gov.vn\%3A443\%2Ftin-noibat\%3Fp_p_id\%3D101_INSTANCE_3Yst7YhbkA5j\%26p_p_lifecycle\%3D0\%26p_p_st ate $\% 3$ Dnormal\%26p_p_mode\%3Dview\%26p_p_col_id\%3Drow-1-column1\%26p_p_col_count $\% 3 \mathrm{D} 1$.

7. Ministry of Health of Vietnam. Tightening the entire system, putting forces in Da Nang. 2020 [cited 2020 02/08]; Available from: https://moh.gov.vn/tin-noi-bat/lasset_publisher/3Yst7YhbkA5j/content/siet-chat-toan-bo-he-thong-don-luc-dap-dich-oa-nang?inheritRedirect=false \&redirect $=$ https $\% 3 \mathrm{~A} \% 2 \mathrm{~F} \% 2 \mathrm{Fmoh} . \mathrm{gov} . v \mathrm{n} \% 3 \mathrm{~A} 443 \% 2 \mathrm{Ftin}-$ noi-

bat\%3Fp_p_id\%3D101_INSTANCE_3Yst7YhbkA5j\%26p_p_lifecycle\%3D0\%26p_p_st ate\%3Dnormal\%26p_p_mode\%3Dview\%26p_p_col_id\%3Drow-1-column$1 \% 26 \mathrm{p} \mathrm{p} \mathrm{col} \mathrm{count \% 3D1.}$

8. Ministry of Health of Vietnam. The Prime Minister instructed: Speed up the tracking of the source of COVID-19 infection. 2020 [cited 2020 02/08]; Available from:

https://moh.gov.vn/hoat-dong-cua-lanh-dao-bo/lasset_publisher/TW6LTp1ZtwaN/content/thu-tuong-chi-ao-tang-toc-truy-vet-nguon-laycovid19? inheritRedirect=false \&redirect=https\%3A\%2F\%2Fmoh.gov.vn\%3A443\%2Fhoatdong-cua-lanh-daobo\%3Fp_p_id\%3D101_INSTANCE_TW6LTp1ZtwaN\%26p_p_lifecycle\%3D0\%26p_p_ 
medRxiv preprint doi: https://doi.org/10.1101/2020.08.27.20183616; this version posted September 7, 2020. The copyright holder for this preprint

(which was not certified by peer review) is the author/funder, who has granted medRxiv a license to display the preprint in perpetuity.

It is made available under a CC-BY-NC 4.0 International license .

state\%3Dnormal\%26p_p_mode\%3Dview\%26p_p_col_id\%3Drow-0-column$2 \% 26 \mathrm{p} \_\mathrm{p} \_$col_count $\% 3 \mathrm{D} 2$.

9. $\quad$ L.Anh and T.Duong. COVID-19 Prevention of community infection: Many measures are applied for the first time. 2020 [cited 2020 02/08]; Available from:

https://tuoitre.vn/phong-chong-covid-19-lay-nhiem-cong-dong-nhieu-bien-phap-lan-dauap-dung-20200727000320695.htm.

10. Nguyen, H.G. and T.V. Nguyen, An epidemiologic profile of COVID-19 patients in Vietnam. medRxiv, 2020.

11. Roser, M., et al., Coronavirus pandemic (COVID-19). Our World in Data, 2020.

12. Ministry of Health of Vietnam, Decision 322/QD-BYT guides the diagnosis and treatment of acute respiratory infections. 2020.

13. Ministry of Health of Vietnam, Decision 1344 / QD-BYT 2020 Guidance on diagnosis and treatment of COVID-19. 2020.

14. Parag Goyal, e.a., Clinical Characteristics of Covid-19 in New York City. NEJM Group Public Health Emergency Collection, 2020.

15. Cao, M., et al., Clinical features of patients infected with the 2019 novel coronavirus (COVID-19) in Shanghai, China. MedRxiv, 2020.

16. Sudharsanan, N., et al., The Contribution of the Age Distribution of Cases to COVID-19 Case Fatality Across Countries: A 9-Country Demographic Study. Annals of Internal Medicine, 2020.

17. Quang Minh. Nearly 7,000 Vietnamese return home due to coronavirus fear in foreign countries. 2020 [cited 2020 31/07]; Available from: http://news.chinhphu.vn/Home/Nearly-7000-Vietnamese-return-home-due-tocoronavirus-fear-in-foreign-countries/20203/39268.vgp.

18. Minh Chien. Chinese people illegally enter Vietnam to travel, find work and go to Cambodia to gamble. 2020 [cited 2020 29/07]; Available from: https://nld.com.vn/thoisu/nguoi-trung-quoc-nhap-canh-trai-phep-vao-viet-nam-de-du-lich-tim-viec-va-sangcampuchia-danh-bai-20200803185032684.htm.

19. Chi Tue and Tien Thang. Preventing 16,000 people from illegally entering Vietnam. 2020 [cited 2020 31/07]; Available from: https://tuoitre.vn/ngan-chan-16-000-nguoi-nhapcanh-trai-phep-vao-viet-nam-20200731183650665.htm.

20. Ministry of Health of Vietnam, Decision 322/QD-BYT 2020; Guidelines for Diagnosis and Treatment of acute respiratory infections caused by a new Corona Virus (2019$n C O V) .2020$.

21. World Health Organization. WHO Coronavirus Disease (COVID-19) Dashboard. 2020 [cited 2020 30/07]; Available from: https://covid19.who.int/.

22. Vo Thu. The third COVID-19 patient in Vietnam died. 2020 [cited 2020 31/07]; Available from: https://ncov.moh.gov.vn/web/guest//benh-nhan-covid-19-thu-3-o-vietnam-tu-vong.

23. Phuong Nguyen and Khanh Vu. 'Act now and act fast': Vietnam says every city at risk of coronavirus. 2020 [cited 2020 29/07]; Available from: https://www.reuters.com/article/us-health-coronavirus-vietnam/vietnam-says-every-cityprovince-now-at-risk-of-virus-infection-idUSKCN24U0C7.

24. Duong Hai. Prof. Dr. Nguyen Van Kinh: "The new virus strain causing COVID-19 spreads rapidly, but its virulence remains unchanged". 2020 [cited 2020 31/07]; 
medRxiv preprint doi: https://doi.org/10.1101/2020.08.27.20183616; this version posted September 7, 2020. The copyright holder for this preprint

(which was not certified by peer review) is the author/funder, who has granted medRxiv a license to display the preprint in perpetuity.

It is made available under a CC-BY-NC 4.0 International license.

Available from: https://ncov.moh.gov.vn/web/guest/-/gs-ts-nguyen-van-kinh-chungvirus-moi-gay-covid-19-lay-lan-nhanh-nhung-oc-luc-khong-oi-. 